\title{
Three Essays on Foreign Entrepreneurs
}

\author{
Elena Kulchina
}

Ph.D. awarded by the University of Toronto, Rotman School of Management, November 2012

TODAY, GLOBAL EXPANSION IS OFTEN seen as a necessary prerequisite for success, but the road to global success is often long and difficult. Strategic issues become particularly complex for foreign entrepreneurs, who in addition to the liabilities of foreignness suffer from a lack of international experience. Despite being faced with unique trade-offs, however, foreign entrepreneurs have received little consideration in the research literature. In my dissertation, I address this gap by examining how foreign entrepreneurs make some of their strategic choices and how these choices influence firm performance.

Foreign entrepreneurs, individuals who establish firms outside of their native countries, are an important phenomenon. In the United States, for example, foreign entrepreneurs own 18\% of small businesses, employing 4.7 million people (Fiscal Policy Institute, 2012). Despite the ubiquity of foreign entrepreneurs, academic work in this area is still relatively sparse: the three most closely related literatures-international entrepreneurship (e.g., Oviatt \& McDougall, 1994), transnational entrepreneurship (e.g., Portes et al., 2002), and immigrant entrepreneurship (e.g., Wilson \& Portes, 1980)-primarily focus on the decisions to become an entrepreneur and to extend operations abroad, whereas other strategic decisions of foreign entrepreneurs remain largely unexplored.

My dissertation comprises three papers exploring different aspects of foreign entrepreneurship. The first paper asks whether foreign entrepreneurial firms perform better with

a foreign owner-manager or a hired domestic manager. The second paper investigates how foreign entrepreneurs' personal relocation preferences may affect their decisions to manage their own firms and draws out implications for venture performance. In the final paper, I explore how media coverage of a city affects location choices of foreign firms and how this effect varies for investors with little private information, such as foreign entrepreneurs.

Each of my dissertation papers examines a unique aspect of foreign entrepreneurship, but all share a common empirical context: foreign firms in Russia between 1997 and 2008. This setting has several attractive features: first, the Ruslana database - a private database comprised of information from Russian government agencies_-provides detailed financial, ownership, top management and location data on a comprehensive sample of foreign firms, including private startups. Second, policy changes in Russia between 1997 and 2008 allow me to more reliably infer causality from the observed empirical relationships.

\section{Study I: Do It Yourself or Hire a Manager? Foreign Entrepreneurs and Firm Performance}

My first study examines the impact of the choice of CEO on the performance of foreign entrepreneurial firms. When starting a firm, an entrepreneur must decide whether to manage it personally or hire a local manager. Yet little is known of how this choice affects firm performance. The theoretical predictions from the existing literature are contradictory: the international business literature suggests that foreign ownermanagers would underperform hired domestic managers because of the liability of foreignness (e.g., Zaheer \& Mosakowski, 1997). The agency literature implies the opposite: owner-managers should exert higher effort because they directly benefit from the firm profit (e.g., Jensen \& Meckling, 1976). I examine this question using a visa policy change as an instrument for the owner-manager choice. I find that manager type significantly affects firm performance: exogenous assignment of a local manager in place of a foreign owner-manager significantly reduces firm

profit. I also demonstrate that, in addition to the reduced agency costs, there is a new mechanism in the international setting: foreign ownermanagers benefit their firms by hiring cheap home-country labor.

This study makes several contributions to the international business literature. First, it is one of the very first studies thus far to examine the

Vol. 13, No. 3 
performance consequences of the choice between a foreign ownermanager and a hired domestic manager. Moreover, while the research in the domestic context frequently attributes the positive owner-manager's effect solely to the reduced agency costs, I show that in the international setting, a significant part of the positive effect comes from entrepreneurs' ability to access home-country resources, such as cheap labor. Furthermore, while the international business literature often finds foreignness to be a liability, I emphasize that foreignness can be beneficial if personal ties outside the region provide access to cheap and mobile resources.

\section{Study II: Private Benefits and Entrepreneurs' Choice of Manager}

In the second study, I focus on the determinants of the choice between an owner-manager and a hired manager. The existing literature has primarily ignored the complexity of this choice and assumed that entrepreneurs always manage their firms themselves (e.g., Nanda \& Sorensen, 2010). As a result, we know very little about what motivates an entrepreneur to manage a firm personally or hire an agent and what are the motivating roles of financial and nonfinancial benefits. I use an example of foreign entrepreneurs who, in order to manage their firms abroad, need to relocate to a host country and, thus, experience nonpecuniary benefits and costs of relocation associated with personally managing the firm. I show that foreign entrepreneurs with high benefits of relocation are more likely to become owner-managers and seem willing to substitute private benefits of relocation for some firm profit.

This paper represents one of the very first attempts to examine the determinants of the entrepreneur's choice to manage a firm personally in an international setting. With caution, my findings can also be extended to other types of international entrepreneurs, returnee-entrepreneurs, and diaspora-entrepreneurs as well as have implications to the choice of manager in multinational corporations, suggesting that expatriate managers' compensation may be contingent on the location attractiveness.

\section{Study III: Media Coverage and Location Choice}

The third study examines the impact of media coverage of a city on the location choices of foreign firms. Emphasizing the importance of informed strategic choice, international business research has examined how private information about locations affects foreign direct investment (FDI) (e.g., Henisz \& Delios, 2001). Publicly available media information has received little attention, however, perhaps because its impact on location choice is expected to be trivial. My study challenges this expectation: Using a new instrument for media coverage (a major anniversary of a city's establishment date), I show that extensive foreign media coverage of a city attracts more foreign firms. This effect is stronger for firms with less private information about Russian cities, i.e., more socially and geographically distant firms and foreign entrepreneurs.
This study explores a previously neglected link between publicly available media information and FDI. While prior research has mainly focused on the impact of private information on location decisions, this study points to the important role of public information. This paper also demonstrates different sensitivity of foreign firms to media coverage in the presence of private signals, which may partially explain the discrepancies in the location choices of international entrepreneurs and multinational corporations, or foreign and domestic firms. Shaver (1998), for example, has found surprisingly different location patterns of foreign and domestic firms in the U.S. My findings suggest that this discrepancy may be partially explained by the different sensitivity of foreign and domestic firms to media signals.

\section{Conclusion}

In summary, this dissertation contributes to the international business literature in several ways: First, it improves our understanding of foreign entrepreneurs - a widespread but understudied phenomenon-by examining their behavior from the social capital and agency perspectives. Second, it examines the antecedents and consequences of important strategic choices, the choices of manager and location, in the international arena. It also extends our understanding of the behavior of foreign firms that could not be explained by the existing theories. For example, it examines the relationship between media signals and FDI and identifies new benefits of owner-management in the international context that have been largely ignored by the existing research.

In addition, this study contributes to the emerging transnational entrepreneurship literature, which examines how foreign entrepreneurs benefit from leveraging their home-country connections. My study suggests how transnational entrepreneurs may benefit from the ties to home-country resources and takes the transnational entrepreneurship literature a step further by suggesting that home-country networks are not equally beneficial for all foreign entrepreneurial firms, but may more strongly benefit firms with foreign owner-managers.

Finally, my findings may also contribute to the international business, entrepreneurship, and strategy education. Traditional curricula and textbooks spend little time on the strategic decisions of foreign entrepreneurs, but may consider including the issues relevant to new international ventures and foreign entrepreneurs. Today, many undergraduate and MBA students come from outside of the United States or Europe and often plan to open their own businesses in the host country after graduation. They would strongly benefit from further discussion of such issues as manager choice or location choice in a young foreign venture.

\section{References}

Fiscal Policy Institute. 2012. Immigrant Small Business Owners. 
Henisz, W.J., \& Delios, A. 2001. Uncertainty, imitation, and plant location: Japanese multinational corporations, 1990-1996. Administrative Science Quarterly 46(3): 443-475.

Jensen, M.C., \& Meckling, W. 1976. Theory of the firm: Managerial behavior, agency costs, and ownership structure. Journal of Financial Economics, 3: 305-360.

Nanda, R., \& Sorensen, J.B. 2010. Workplace Peers and Entrepreneurship. Management Science, 56(7): 1116-1126.

Oviatt, B. M., \& McDougall, P. P. 1994. Toward a theory of international new ventures. Journal of International Business Studies, 25(1): 4564.

Portes, A., Fuarnizo, L.E., \& Haller, W.J. 2002. Transnational entrepreneurs: An alternative form of immigrant economic adaptation. American Sociological Review, 67(2): 278-298.

Shaver, J.M. 1998. Do foreign-owned and U.S.-owned establishments exhibit the same location pattern in U.S. manufacturing industries? Journal of International Business Studies 29 (3): 469-492.

Wilson, K.L., \& Portes, A. 1980. Immigrant enclaves: An analysis of the labor market experiences of Cubans in Miami. American Journal of Sociology, 86: 295-319.

Zaheer, S., \& Mosakowski, E. 1997. The dynamics of the liability of foreignness: A global study of survival in financial services. Strategic Management Journal, 18 (6): 439-464.

Elena Kulchina is an Assistant Professor of Strategy at Duke University. She received her Ph.D. in Management from the University of Toronto. Her research is at the intersection of international business, strategic management and entrepreneurship. She studies the strategic behavior of foreign entrepreneurs and new organizations in the international arena. Her research has won the NFIB Doctoral Dissertation Award in Entrepreneurship from the Academy of Management and is forthcoming in the Strategic Management Journal. 